\section{Primary Structure of Rice Cytochrome $\mathrm{c}$}

\section{Eigo MORI and Yuhei Morita}

The Research Institute for Food Science, Kyoto University, Uji 611, Japan

Received February 13, 1978

The primary structure of cytochrome c from many plants has been determined to construct a phylogenetic tree for higher plants, ") although little work has been done on monocotyledonous species. As the primary structure of plant cytochrome $c$ differs in certain characteristic features from that of vertebrates, ${ }^{2}$ " the determination of the three-dimensional structure of plant cytochrome $c$ will provide valuable information on the structurefunction relationship of the molecule. Morita and $\mathrm{Ida}^{3}$ have reported preliminary crystallographic data for the hexagonal crystals of cytochrome $\mathrm{c}$ from rice embryos, and further structural investigation is under way. In this communication we describe the primary structure of rice cytochrome $c$.

Rice cytochrome c with an $A_{550}$ (red) $/ A_{280}$ (ox) ratio of 1.03 was used in the sequence study, ${ }^{4}$ and was denatured with ethanol according to the method of Margoliash et $a l^{5)}$ Cleavage of the denatured protein $(5.9 \mu$ moles $)$ at two methionine sites with cyanogen bromide (CNBr) by the method of Steers $e t a l^{6)}$ yielded three major fragments (I, II and III) with overlapping fragments and the unreacted protein in minor quantities. These fragments were separated by gel filtration on Sephadex G-75 and -50 columns, followed by Aminex 50W-X2 column chromatography. The $\mathrm{CNBr}$ peptides I and II each contained one homoserine or homoserine lactone, whereas III contained neither. Peptide I was also found to contain the $\mathrm{N}$-terminus of the protein. Therefore, the $\mathrm{CNBr}$ peptides must be aligned: I-II-III. The final yields of the purified peptides were: I (residues -8 to 55 ) $15 \%$, II (56 to 80$) 8.1 \%$, III (81 to 103$) 28 \%$. Pepti- des I and III were further fragmented by trypsin and II by chymotrypsin at pH 8.0 and at $37^{\circ} \mathrm{C}$. The tryptic and chymotryptic peptides were fractionated on an Aminex 50W$\mathrm{X} 2$ column $(0.8 \times 65 \mathrm{~cm})$ and purified on Sephadex G-50, -25 and -15 columns $(1.5 \times$ $240 \mathrm{~cm}$ ) or by high-voltage paper electrophoresis at $\mathrm{pH} 6.5$ or $\mathrm{pH}$ 1.9. The yields and charge at $\mathrm{pH} 6.5$ of these purified peptides were: IT $1,43 \%, 0$; IT $2,23 \%$, 0; IT3, $66 \%$, +1 ; IT4, $15 \%$, N. D.; IT5, $23 \%$, 0; IT6, $56 \%$, N. D.; IT7, 18\%, 0; IT8, 9.5\%, -1; IT9, 12\%, 0 ; IICl, $50 \%$, N. D.; IIC2, 32\%, N. D.; IIC 2 ' $48 \%$, N. D.; IIC3, 67\%, N. D.; IIIT1, $65 \%,+2 ;$ IIIT $2,70 \%,-1$; IIIT3, $81 \%,+1$; IIIT4, 75\%, -1, where N. D. means "not determined." To align these peptides derived from $\mathrm{CNBr}$ fragments the overlapping peptides were obtained from the chymotryptic digest of the denatured protein $(2.0 \mu$ moles $)$. Fourteen peptides were purified by similar procedures. Their yields and charge at $\mathrm{pH} 6.5$ were: C1, $54 \%$, N.D.; C2, $56 \%, 0 ; \mathrm{C} 3,9.3 \%$, N.D.; C4, 30\%, 0; C5, 32\%, 0; C6, 24\%, 0; C7, $8.6 \%$, N.D.; C8, 43\%, - 2; C9, $26 \%,+1$; $\mathrm{C}^{\prime}, 8.7 \%,+2$; C9", $25 \%$, N.D.; C10, $41 \%$, $+1 ; \mathrm{Cl1}, 47 \%$, N.D.; C12, 59\%, 0, where N.D. means "not determined." Peptide numbering is based on the position of the peptide in the complete amino acid sequence of the protein starting at the N-terminus, and the residue number is based on vertebrate cytochrome c numeration.

Amino acid analyses were performed with a Hitachi KLA-5 amino acid analyzer or a micro-amino acid analyzer $(1 \sim 10$ nmoles $)$ constructed by Hayashi. Lysine and $\varepsilon-\mathrm{N}$ trimethyllysine (TML) were separated in the amino acid analysis, as described by Hempel

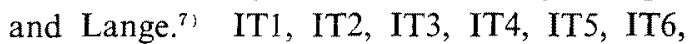
IIC3, IIIT1, IIIT2, IIIT3, IIIT4, C4, C5, C6, $\mathrm{C} 7, \mathrm{C} 8$ and $\mathrm{C} 9$ were sequenced by the subtractive Edman method. ${ }^{8)}$ The others were suquenced by the Edman-Dansyl method ${ }^{91}$ directly or on subfragments after thermolytic digestion ( $\mathrm{C} 2$ and $\mathrm{C} 11)$ or chymotryptic digestion (IT1). The C-terminal sequence of peptides was determined by carboxypeptidase 
Ac-Ala-Ser-Phe-Ser-Glu-Ala-Pro-Pro-Gly ${ }^{-8}$-Asn-Pro-Lys-Ala -Gly-Glu-Lys-Ile-Phe -

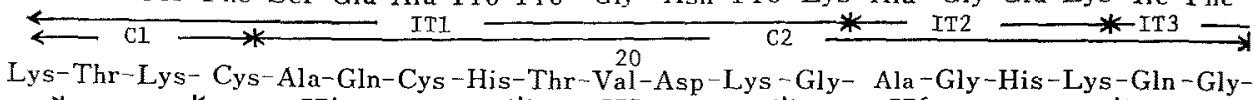

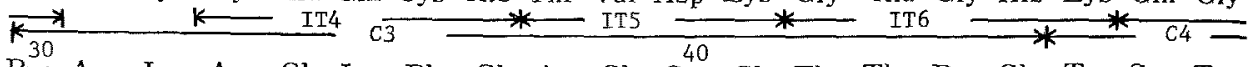
Pro-Asn-Leu-Asn-Gly-Leu-Phe-Gly-Arg-Gln-Ser-Gly-Thr-Thr-Pro-Gly-Tyr-Ser-Tyr$=$ IT7

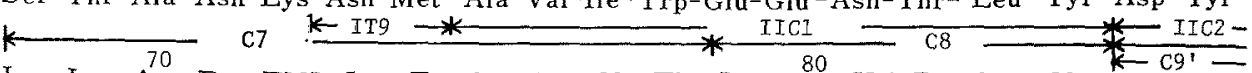
Leu-Leu-Asn-Pro-TML-Lys-Tyr-Ile-Pro-Gly-Thr-Lys-Met-Val-Phe-Pro-Gly-Leu-TML-

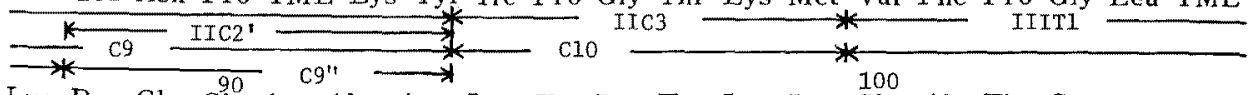

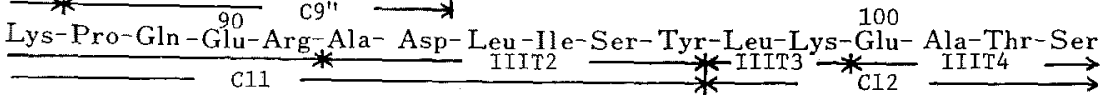

FIG. 1. The Complete Amino Acid Sequence of Rice Cytochrome c.

The residue numbers used in this figure are based on vertebrate cytochrome $c$ numeration. The Roman numbers refer to CNBr peptides. The prefix $T$ refers to purified tryptic peptides, and the prefix $\mathrm{C}$ to purified chymotryptic peptides. $\mathrm{TML}=\varepsilon-\mathrm{N}$-trimethyllysine.

\section{A, B or $\mathrm{Y}$ digestion methods. ${ }^{10,11)}$}

The complete amino acid sequence of rice cytochrome $\mathrm{c}$ is shown in Fig. 1. The amides were assigned by the method of Offord ${ }^{12}$ but $G \ln ^{28}, A s n^{31}, \mathrm{Asn}^{33}, \mathrm{Gln}^{39}, \mathrm{Asn}^{62}, \mathrm{Gln}^{89}$ and $\mathrm{Glu}^{90}$ were assigned by homology with the sequences of other plant cytochromes $c$ already reported. The primary structure of rice cytochrome $c$ has general features common to other plant cytochromes c, i.e., an $\mathrm{N}$ acetylated 'tail' of eight residues and two TML residues in positions 72 and 86 . However, the residue in position 96 in rice cytochrome $c$ is serine, the same as in Ginkgo, whereas other plant cytochromes $c$ so far examined have alanine in this position. The experimental details of sequence determination will be described elsewhere along with a discussion of taxonomical comparison and structural homology. ${ }^{13)}$

Acknowledgement. The authors with to thank Dr. R. Hayashi, associate professor of Kyoto University, for giving helpful advice and providing facilities. They also thank Dr. S. Aibara for advice and discussions.

\section{REFERENCES}

1) D. Boulter, Pure Appl. Chem., 34, 539 (1973).

2) D. Boulter and J. A. M. Ramshaw, Phytochemistry, 11, 553 (1972).

3) Y. Morita and S. Ida, J. Mol. Biol., 71, 807 (1972).

4) S. Ida and Y. Morita, Agric. Biol. Chem., 33, 10 (1969).

5) E. Margoliash, J. R. Kimmel, R. L. Hill and W. R. Schmidt, J. Biol. Chem., 237, 2148 (1962).

6) E. Steers, G. R. Craven, C. B. Anfinsen and J. L. Bethune, J. Biol. Chem., 240, 2478 (1965).

7) K. Hempel and H.-W. Lange, Z. Physiol. Chem., 349, 603 (1968).

8) W. Konigsberg, "Methods in Enzymology," Vol. XXV, Part B, ed. by C. H. W. Hirs and S. N. Timasheff, Academic Press Inc., New York, N. Y., 1972, p. 326.

9) W. R. Gray and B. S. Hartley, Biochem. J., 89, 379 (1963); 89, 59 p (1963).

10) R. P. Ambler, "Methods in Enzymology," Vol. XXV, Part B, ed. by C. H. W. Hirs and S. N. Timasheff, Academic Press Inc., New York, N. Y., 1972, p. 143.

11) R. Hayashi, S. Moore and W. H. Stein, J. Biol. Chem., 248, 2296 (1973).

12) R. E. Offord, Nature, 211, 591 (1966).

13) Y. Morita, E. Mori and S. Aibara, in preparation. 